\title{
Determination of Anti-oxidative and Whitening Effects of Complex Extracts Obtained from Sprout Panax ginseng C.A. Meyer and Cassia nomame (Sieb.) Honda on Skin
}

\author{
Geon-Woo Kim ${ }^{1}$, Yun-Hee Choi ${ }^{1}$, Byung-Loc Kim ${ }^{1}$, Yonguk Kim ${ }^{1}$, Rack-Seon Seong ${ }^{1}$, Min-Hee Han ${ }^{1}$, Gyeong-Ae Kim ${ }^{2}$, Min-Ju Choi ${ }^{2}$, Yong-Gi \\ Jeong $^{1 *}$ \\ ${ }^{1}$ Center of Natural Resources Research, Jeonnam Bioindustry Foundation, Jangheung-gun, Jeollanam-do, Korea \\ ${ }^{2}$ R\&D Lab., HAYON Co., Ltd., Gwangju, Korea
}

\author{
*Corresponding author: Yong-Gi Jeong, Center \\ of Natural Resources Research, Jeonnam \\ Bioindustry Foundation, 288 Woodland-gil, \\ Anyang-myeon, Jangheung-gun, Jeollanam-do \\ 59338, Korea \\ Tel.: +82618602630 \\ Fax: +82618647105 \\ Email: go6115@nate.com
}

Received December 29, 2017

Revised June 5, 2018

Accepted July 5, 2018

Published September 30, 2018

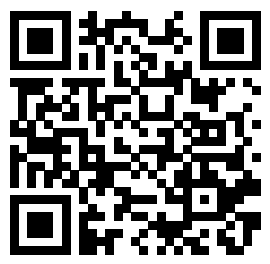

\begin{abstract}
Purpose: In this study, we tried to develop differentiated natural cosmetic materials through the standardization of optimal raw materials, and demonstrate complex functionality with anti-oxidative and whitening effects of natural extracts of sprout Panax ginseng C.A. Meyer and Cassia nomame (Sieb.) Honda. Methods: In this experiment, the research materials, sprout Panax ginseng C.A. Meyer and Cassia nomame (Sieb.) Honda, were prepared by identification of genetic analysis, complex extracts of sprout Panax ginseng C.A. Meyer and Cassia nomame (Sieb.) Honda were determined to have optimum anti-oxidative and whitening effects by studying the mixture ratio, solvent ratio, extraction temperature, and extraction time. The standard compound was prepared from the final complex extract. Results: The mixture ratio of sprout Panax ginseng C.A. Meyer and Cassia nomame (Sieb.) Honda with optimum anti-oxidative and whitening effects was 1:9, extraction solvent was $30 \%$ ethanol, extraction temperature was $80^{\circ} \mathrm{C}$ and extraction time was $8 \mathrm{~h}$. The antioxidative activity of the complex extract showed 49.6\% 1.1-diphenyl-2-picrylhydrazyl (DPPH) radical scavenging activity at $500 \mu \mathrm{g} / \mathrm{mL}$. In a tyrosinase inhibitory activity assessment, the complex extract showed $109 \%$ tyrosinase inhibitory activity at 2,000 $\mu \mathrm{g} / \mathrm{mL}$. The standard compound was confirmed to be Schaftoside. Conclusion: This study reveals key conditions for the standardization of manufacturing process to obtain optimal anti-oxidative and whitening effects from complex extracts of sprout Panax ginseng C.A. Meyer and Cassia nomame (Sieb.) Honda. We expect that the use of industrial cosmetics as raw materials for cosmetics, including Shaftoside, will not be hampered by limitations in industrial use due to international patent disputes and high costs.
\end{abstract}

Keywords: Sprout Panax ginseng C.A. Meyer, Cassia nomame (Sieb.) Honda, Antioxidative, Whitening, Schaftoside

\section{Introduction}

전 세계 천연화장품 시장규모가 꾸준히 성장하고 있는 것과 관 련하여 천연화장품 개발이 활발히 이루어지고 있으며 그 중 주름 개선, 미백, 항염증 등과 관련된 화장품 생산의 증가율과 점유율 이 높게 나타나고 있다(Yoo et al., 2004). 국내에서도 전 세계 동향과 유사하게 미백, 주름개선, 항염증과 관련된 천연화장품
제품이 증가하고 있다(Kim, 2006). 향후 천연화장품은 산업적, 기술적인 성장세가 예상되며 특히 산업현장의 요구와 소비자 선 호도가 충분히 확인된 만큼 안전성, 효능 개선 등에 대한 연구결 과가 입증된다면 지속적인 발전이 가능할 것으로 예상된다(Choe \& Choe, 2014; Han \& Yi, 2012).

본 연구 소재인 새싹인삼(sprout Panax ginseng C.A. Meyer)은 천연소재로써 새싹삼 또는 인삼새싹이라고 하며, 2년 
미만의 인삼을 2-4개월 수경재배로 키우는 것이 특징이다. 또 다른 소재인 차풀은 며느리감나무, 생약명으로는 산편두, 학명으 로는 Cassia nomame (Sieb.) Honda로 불리우며, 한국, 중국 등지에 분포하는 콩과의 한해살이 식물로 높이 30-60 $\mathrm{cm}$ 에 이 른다. 잎은 줄모양의 타원형으로 어긋나 자라며, 꽃은 7-8월에 피는 노란색 꽃으로, 열매는 편평한 타원형이다. 종자는 검은색 으로 광택이 있고, 냇가 근처의 양지에서 자라며, 결실기는 10 월 이다. 새싹인삼뿐만 아니라 차풀 역시 식물의 전체부위(일명 전 초)가 식용 가능한 원료로써 별도의 화장품 원료 등록 절차 없이 바로 사용이 가능한 천연소재이다(Jo et al., 2011; Lee et al., 2010; Rhim et al., 2009). 따라서 본 연구에서는 천연소재인 새싹인삼과 차풀의 복합추출물을 이용하여 항산화 및 미백효과 를 입증하고, 지표물질의 설정을 통해 차별화된 천연화장품 소재 를 개발하고자 하였다.

\section{Methods}

\section{1. 새싹인삼과 차풀 시료준비}

새싹인삼은 전남 장성군에 위치한 윤희네 농장(Korea)에서 구 입하였으며 채취시기 7월-8월에 해당하는 전초를 사용하였다. 차풀은 9월-10월 사이에 채취한 전초를 사용하였으며, 강원도 삼척시 자연약초 농장(Korea)에서 구입하였다. 보통 새싹인삼은 뿌리 부분만을 사용하는 경우가 많았으나 본 연구에서는 뿌리, 줄기 및 잎을 포함하는 새싹인삼의 전 부위를 원료로써 사용하였 다(Lee et al., 2010). 차풀 또한 뿌리를 제거하지 않은 전초를 세척한 후 물기를 건조하여 준비하였으며, 건조된 시료는 $-20^{\circ} \mathrm{C}$ 냉동고에 보관 후 실험에 사용하였다.

\section{2. 새싹인삼과 차풀의 유전분석}

본 실험에 사용된 새싹인삼과 차풀은 각각 전남 장성 농장과 강원도 삼척에서 구입 후, 세척 및 건조하였으며 $\mathrm{DNA}$ 추출 전 까지 $-80^{\circ} \mathrm{C}$ 에서 보관하여 실험을 진행하였다. Genomic DNA 를 분리하기 위해 채취한 시료 $0.3 \mathrm{~g}$ 을 pestle을 사용하여 액체 질소 상에서 아주 곱게 간 후 DNeasy Plant mini kit (Qiagen, Germany)를 사용하여 매뉴얼에 따라 $\mathrm{DNA}$ 를 추출하였다. 추출 한 DNA는 NanoDropTM (ThermoFisher Scientific, USA)으 로 DNA 정량을 실시하여 $50 \mathrm{ng} / \mu \mathrm{L}$ 으로 희석하여 polymerase

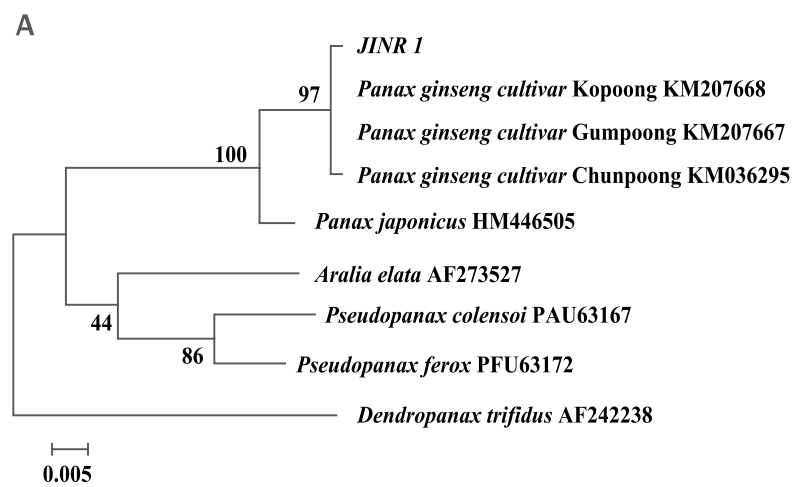

B

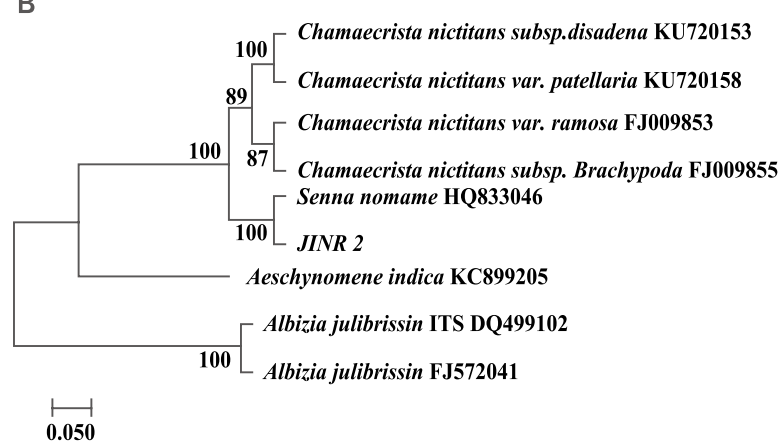

Figure 1. Molecular phylogenetic analysis of sprout Panax ginseng and Cassia nomame using a maximum likelihood method.

(A) NCBI BLAST search of sprout Panax ginseng C.A. Meyer (JINR 1), (B) NCBI BLAST search of Cassia nomame (Sieb.) Honda (JINR 2).

chain reaction (PCR)에 사용하였다. 차풀의 Internal Transcribed Spacer (ITS) 영역을 증폭하기 위해 universal ITS 영역 증폭 primer를 사용하여 PCR을 실시하였다(Chen et al., 2010). PCR 조건은 $50 \mathrm{ng} / \mu \mathrm{L}$ genomic DNA, $1 \mathrm{U} \mathrm{Ex}$ Taq polymerase (TaKaRa), $1 \times$ PCR buffer $(50 \mathrm{mM} \mathrm{KCl,} 10$ mM Tris-HCl, pH8.3), $200 \mu \mathrm{M}$ dNTPs, 5 pM forward 및 reverse primer (Table 1)를 넣고 총량을 3차 증류수로 $50 \mu \mathrm{L}$ 가 되도록 맞추었다.

반응조건은 먼저 $95^{\circ} \mathrm{C}$ 에서 $5 \mathrm{~min}$ 초기 변성(denaturation) 을 한 다음, $95^{\circ} \mathrm{C}$ 에서 $30 \mathrm{~s}$ 변성(denaturation), $55^{\circ} \mathrm{C}$ 에서 $30 \mathrm{~s}$ 풀림(annealing), $72^{\circ} \mathrm{C}$ 에서 $30 \mathrm{~s}$ 확장(extension)하여 40 회 반 응시킨 후 마지막에 $72{ }^{\circ} \mathrm{C}$ 에서 $5 \mathrm{~min}$ 확장(extension)하였으며,

Table 1. PCR primers used in this study

\begin{tabular}{ll}
\hline Primer & Sequences \\
Forward & CCTTATCATTTAGAGGAAGGAG \\
Reverse & TCCTCCGCTTATTGATATGC \\
\hline
\end{tabular}

PCR, polymerase chain reaction 

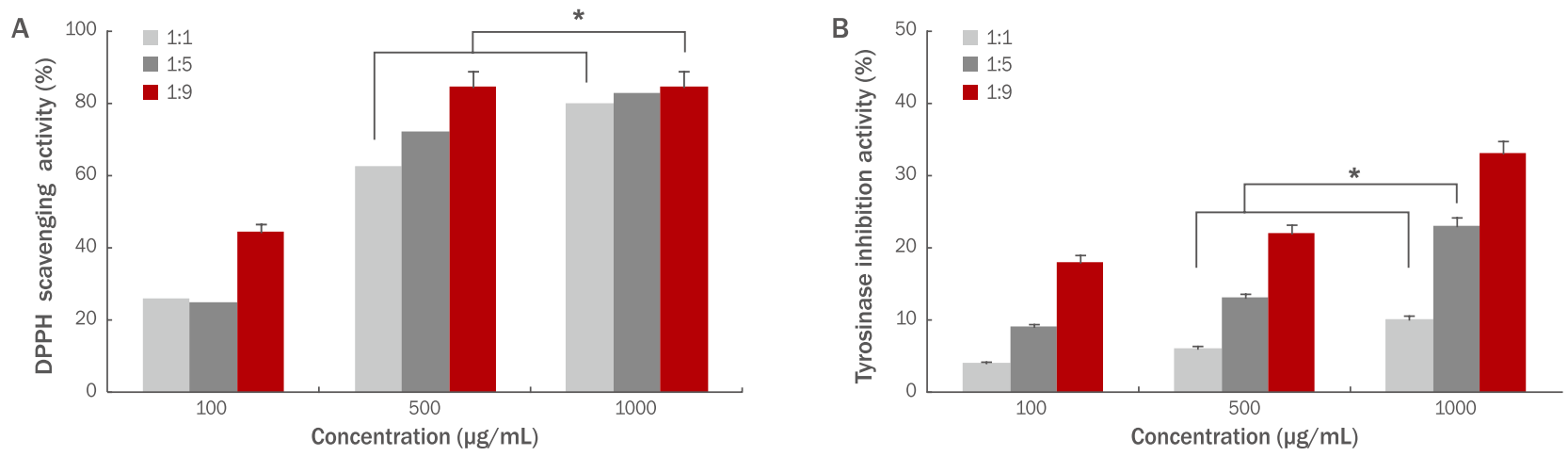

Figure 2. DPPH radical scavenging activity (A) and tyrosinase inhibitory activity (B) by combination ratio of complex extracts using sprout Panax ginseng C.A. Meyer: Cassia nomame (Sieb.) Honda.

Extracts were freeze-dried, and dissolved in 50\% DMSO. Diluted extracts were mixed with $0.15 \mathrm{mM}$ DPPH in methanol. After 30 min incubation at room temperature, read the absorbance at $517 \mathrm{~nm}$. Mush room tyrosinase was mixed with $220 \mu \mathrm{L}$ of phosphate buffer $(0.1 \mathrm{M}, \mathrm{pH} 6.5)$ and $40 \mu \mathrm{L}$ of $1.5 \mathrm{mM}$ tyrosine and $20 \mu \mathrm{L}$ of different concentrated extracts. The mixture was then incubated for $15 \mathrm{~min}$ at $37^{\circ} \mathrm{C}$. Following incubation, absorbance of the mixture was determined at $490 \mathrm{~nm}$. DPPH radical scavenging activity and tyrosinase inhibitory activity by combination ratio of complex extracts showed relatively high DPPH and tyrosinase inhibitory activity. Each bar indicates the mean \pm standard deviation $(S D)$ of determinations $(n=3)$. Statistical analysis was performed with a one-way ANOVA ( $\left.{ }^{*} p<0.05\right)$. DPPH, 1.1-diphenyl-2-picrylhydrazyl; DMSO, dimethyl sulfoxide.

각 $\mathrm{PCR}$ 증폭 산물은 $1.5 \%$ agarose gel에 전기영동을 하고 UV transilluminator (UVITec Cambridge, UK)를 이용하여 DNA 밴드를 확인하였다.

새싹인삼과 차풀의 $18 \mathrm{~S}$ 유전자의 염기서열을 밝히기 위하 여 ITS primer set에 의해 증폭된 PCR 산물(약 700bp)을 QIAquick ${ }^{\circledR}$ Gel extraction kit (Qiagen)를 이용하여 회수하 였으며, Enzynomics 사(Korea)의 TOPcloner ${ }^{\mathrm{TM}} \mathrm{TA}$ kit를 사 용하여 매뉴얼에 따라 TA cloning을 진행하였으며 염기서열 을 확인하기 위한 sequencing은 Cosmogentech (Korea)에 의 뢰하여 진행하였다. 새싹인삼과 차풀의 염기서열은 Mega 7.0 (Edgar, 2004)과 CLC sequence viewer version 6.9 (CLC Bio, Denmark)를 사용하여 NCBI의 GeneBank의 유전자 정보 와 multiple alignment를 실시하였고 MEGA 7.0의 최대우도 법(maximum likelihood method)으로 계통수를 생성하고 판 독하여 계통도를 작성하였다. 계통수에 대한 신뢰도는 부트스트 랩(bootstrap) 값을 500회 반복하여 평가하였다(Rhim et al., 2010).

\section{3. 새싹인삼과 차풀 복합추출물의 최적 배합비율}

새싹인삼과 차풀 복합추출물을 제조하기 위하여 새싹인삼과 차풀의 배합비율(중량 비), 추출 용매, 추출 온도, 추출시간에 따 른 항산화 및 미백효과(tyrosinase 저해)를 측정하여 최적의 추 출 조건을 확인하였다(Jeon et al., 2015).

항산화와 미백효과가 가장 우수한 새싹인삼과 차풀의 최적 배 합비율을 찾기 위하여 새싹인삼과 차풀의 배합비율(중량비)을 $3: 1,2: 1,1: 1,1: 2,1: 3,1: 4,1: 5,1: 6,1: 7,1: 8$ 및 1:9로
하여 열수추출을 수행하였다. 열수추출은 $80^{\circ} \mathrm{C}$ 에서 $8 \mathrm{~h}$ 동안 수 행하는 조건으로 고정하여 수행하고, 추출된 새싹인삼과 차풀 복 합추출물에 대하여 동결건조를 수행한 후 항산화 및 미백효과를 측정하였다.

\section{4. 새싹인삼과 차풀 복합추출물의 최적 추출용매 및 용매비율}

가장 우수한 항산화 효과를 보이는 배합비율을 선택 후 물, $10 \%$ 에탄올(DUKSAN, Korea), $20 \%$ 에탄올 및 $30 \%$ 에탄올 을 사용하여 새싹인삼과 차풀 복합추출물을 추출하였다. 추출은 $80^{\circ} \mathrm{C}$ 에서 $8 \mathrm{~h}$ 동안 수행하는 조건으로 고정하여 수행하였으며, 추출된 새싹인삼과 차풀 복합추출물에 대하여 동결건조를 수행 한 후 항산화 및 미백효과를 측정하였다.

\section{5. 새싹인삼과 차풀 복합추출물의 최적 추출온도 및 추출시간}

배합비율과 추출 용매를 결정한 후 온도에 따른 활성을 확인하 기 위하여 추출온도를 $20^{\circ} \mathrm{C}, 40^{\circ} \mathrm{C}, 60^{\circ} \mathrm{C}, 80^{\circ} \mathrm{C}$ 및 $100^{\circ} \mathrm{C}$ 로 하 고, $8 \mathrm{~h}$ 동안 추출하였다. 또한, 최적 추출시간을 확인하기 위하 여 2-12 h까지 $2 \mathrm{~h}$ 간격으로 추출을 수행하였으며, 추출된 새 싹인삼과 차풀 복합추출물에 대하여 동결건조를 수행한 후 항산 화 및 미백효과를 측정하였다.

\section{DPPH 라디칼 소거능 측정}

새싹인삼과 차풀 복합추출물의 항산화 효능 평가는 Blois 방법 을 변형하여 측정하였다(Jeong \& Kim, 2016). 각 농도별 희석 시료액 $20 \mu \mathrm{L}$ 와 $0.15 \mathrm{mM}$ DPPH (Sigma-Aldrich, USA) 200 $\mu \mathrm{L}$ 를 혼합한 후 $30 \mathrm{~min}$ 암실 반응하였다. 그 후 microplate 

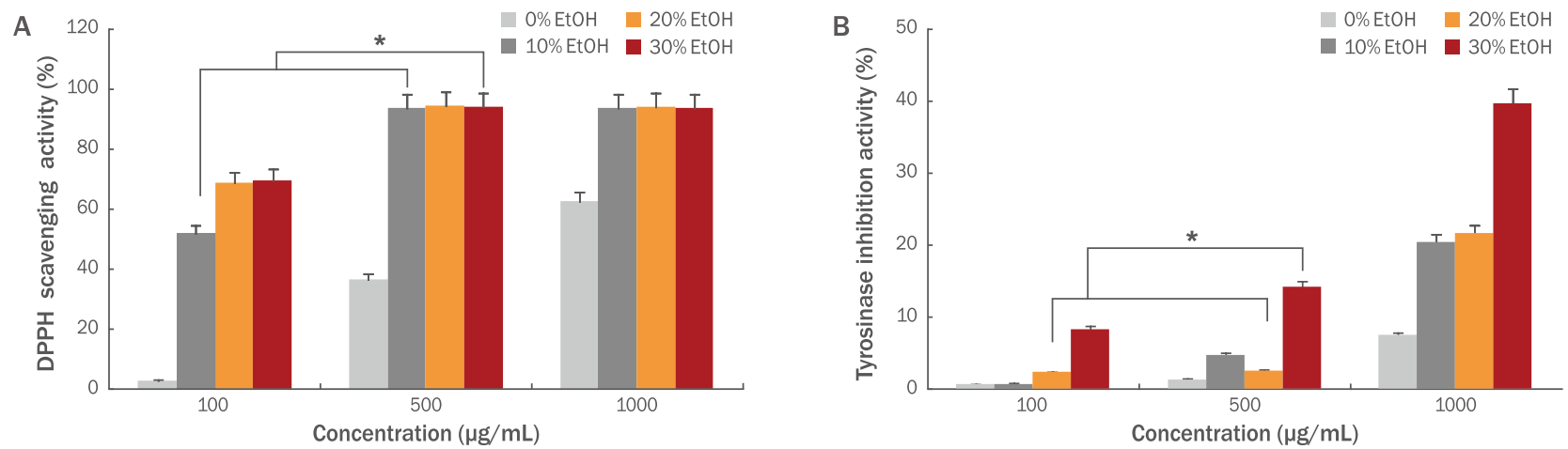

Figure 3. DPPH radical scavenging (A) and tyrosinase inhibitory activity (B) by solvent ratio of complex extracts using sprout Panax ginseng C.A. Meyer and Cassia nomame (Sieb.) Honda.

Extracts were freeze-dried and dissolved in 50\% DMSO. Each solvent ratio of complex extracts at various concentrations (100, $500,1,000 \mu \mathrm{g} / \mathrm{mL}$ ) was interacted with DPPH and tyrosinase inhibitory activity. DPPH radical scavenging activity and tyrosinase inhibitory activity by solvent ratio of complex extracts showed relatively high DPPH and tyrosinase inhibitory activity. Each bar indicates the mean \pm standard deviation of determinations $(n=3)$. Statistical analysis was performed with a one-way ANOVA $\left({ }^{*} p<0.05\right)$. DPPH, 1.1-diphenyl-2-picrylhydrazyl; DMSO, dimethyl sulfoxide.

reader SpectraMax 190 (Molecular Device, USA)를 이용하 여 $517 \mathrm{~nm}$ 에서 흡광도를 측정하는 방법으로 라디칼 소거능을 확인하였다. 소거능은 시료 첨가구와 무첨가구의 흡광도 차이를 백분율 $(\%)$ 로 구하였다.

$\mathrm{DPPH}$ 라디칼 소거능 $(\%)=[1-(\mathrm{A} / \mathrm{B})] \times 100$
$\mathrm{A}$ : 시료 첨가구 흡광도
$\mathrm{B}$ : 시료 무첨가구 흡광도

\section{Tyrosinase 저해 활성}

새싹인삼과 차풀 복합추출물의 미백효과는 tyrosinase의 저 해 활성을 측정하여 확인하였다. $0.1 \mathrm{M}$ sodium phosphate ( $\mathrm{pH}$ 6.5) buffer (Junsei, Japan) $220 \mu \mathrm{L}$, 시료액 $20 \mu \mathrm{L}$, $1500 \mathrm{U} / \mathrm{mL}$ tyrosinase (Sigma-Aldrich) $20 \mu \mathrm{L}, 1.5 \mathrm{mM}$ tyrosine (Sigma-Aldrich) $40 \mu \mathrm{L}$ 를 순서대로 혼합하고, 혼합 액을 $37^{\circ} \mathrm{C}$ 에서 $10 \mathrm{~min}$ 동안 반응시킨 후 $490 \mathrm{~nm}$ 에서 흡광도 를 측정하였다(Kwon, 2015).

Tyrosinase 활성 저해율 $(\%)=\left[100-\left(B-B^{\prime} / A-A^{\prime}\right)\right] \times 100$
$\mathrm{A}$ : 공시료액의 반응 후의 흡광도

$\mathrm{B}$ : 시료액의 반응 후의 흡광도

$\mathrm{A}^{\prime}, \mathrm{B}^{\prime}$ : tyrosinase 대신 0.1 M sodium phosphate (pH 6.5) 로 대체하여 측정한 흡광도

\section{8. 지표성분 확인}

새싹인삼과 차풀 복합추출물에 대하여 high performance liquid chromatography (HPLC) 분석 및 matrixassisted laser desorption ionization time of flight mass spectrometer (MALDI-TOF/MS) 실험을 수행하여 복합추출 물의 지표물질을 설정하였다. 복합추출물은 Triart C18 PLUS column (S-5 m, $250 \times 4.6$ mm l.D.; YMC, Japan)을 이용 하여(Hur et al., 2010; Kim et al., 2014), injection volume $10 \mu \mathrm{L}$, flow rate $1 \mu \mathrm{L} / \mathrm{min}$, 온도는 $37^{\circ} \mathrm{C}$ 조건에서 분석하 였다. HPLC system은 pump LC30AD XR, Auto-sampler SIL-20AXR, UV-VIS detector (SPD 20A; Shimadzu, Japan)를 사용하였으며 solvent 조건은 $0.01 \%$ formic acid

Table 2. Solvent and experimental conditions of HPLC

\begin{tabular}{|c|c|c|}
\hline Time (min) & Water (\%) & Acetonitrile (\%) \\
\hline 0 & 84 & 16 \\
\hline 20 & 84 & 16 \\
\hline 25 & 0 & 100 \\
\hline 32 & 0 & 100 \\
\hline 37 & 84 & 16 \\
\hline 45 & 84 & 16 \\
\hline
\end{tabular}

Water and acetonitrile both include $0.01 \%$ formic acid. HPLC, high performance liquid chromatography. 

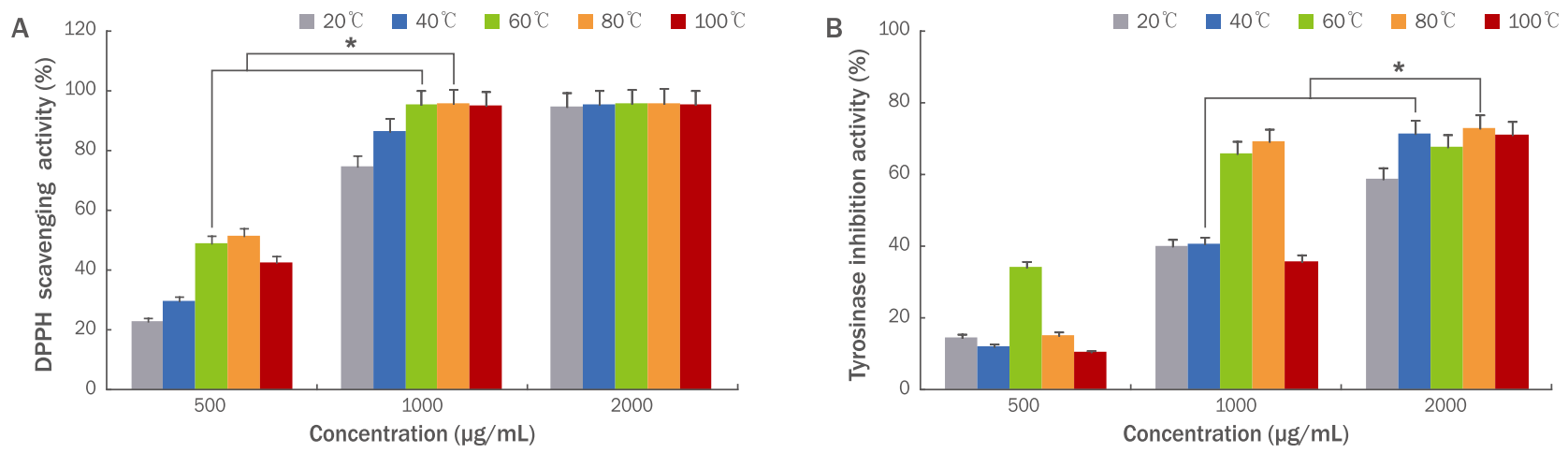

Figure 4. DPPH radical scavenging (A) and tyrosinase inhibitory activity (B) by temperature of complex extracts using sprout Panax ginseng C.A. Meyer and Cassia nomame (Sieb.) Honda.

Extracts were freeze-dried and dissolved in 50\% DMSO. Each extraction temperature at various concentrations $(500,1,000$, $2,000 \mu \mathrm{g} / \mathrm{mL}$ ) was interacted with DPPH and tyrosinase inhibitory activity. DPPH radical scavenging activity and tyrosinase inhibitory activity by temperature were displayed in a dose-dependent manner. Each bar indicates the mean \pm standard deviation of determinations $(n=3)$. Statistical analysis was performed with a one-way ANOVA $\left({ }^{*} p<0.05\right)$. DPPH, 1.1-diphenyl-2-picrylhydrazyl; DMSO, dimethyl sulfoxide.

(J.T. Baker®, USA)가 포함된 물과 acetonitrile (ACN; J.T. Baker®)로 물과 ACN의 비율을 조절하여 Table 2 와 같이 수 행하였다. 분획한 후보 지표물질에 대하여 ultra-fast liquid chromatography coupled with ion trap time of flight mass spectrometer (UFLC IT TOF/MS, LCMS-IT-TOF; Shimadzu)를 이용하여 질량분석을 수행하였으며, 이를 데이터 베이스에 비교하여 지표물질을 확인하였다.

\section{9. 통계분석}

본 실험 결과는 GraphPad 프로그램(GraphPad Software, $\mathrm{USA})$ 을 이용하여 평균값과 표준편차를 산출하였다. 각 군간의 유의성은 일원분산분석(one-way analysis of variance, Oneway ANOVA) 시행 후 모든 처리 값의 차이는 신뢰수준 $95 \%$ $(p<0.05)$ 로 검증하였다.

\section{Results and Discussion}

\section{1. 새싹인삼과 차풀의 유전분석}

새싹인삼과 차풀의 유전분석을 위하여 $\mathrm{PCR}$ 후 $\mathrm{TA}$ cloning 방법(Yang et al., 2012)으로 ITS 염기서열을 확인하였다. 그 결과 새싹인삼은 염기서열의 재배열(multiple alignment)을 통 해 고려인삼 품종인 검풍, 고풍과 $100 \%$, 춘풍과 $99 \%$ 이상의 상동성(homology)이 있음을 확인하였다(Rhim et al., 2010). 미국 국립생물정보센터(national center for biotechnology information, NCBI)의 유전자은행(GeneBank)에 등록되어 있 는 인삼속(Panax)의 종(species)들과의 계통 분석에서는 새싹
인삼이 고려인삼 품종과 같은 분계조를 형성하며 $97 \%$ 의 확률로 유전적 신뢰도를 가지고 있음을 확인하였다. 따라서 새싹인삼 은 고려인삼의 품종과 유전적으로 일치함을 확인하였다(Figure 1A).

차풀도 새싹인삼과 동일한 방법으로 염기서열을 재배열하여 Senna nomame HQ833046과 99\%의 상동성이 있음을 확인하 였다. 또한 미국 국립생물정보센터의 유전자 은행에 등록되어 있는 차풀속(Chamaecrista)의 종(species)들과의 근연 관계를 maximum likelihood method (Tamura \& Nei, 1993)로 계통 분석을 실시한 결과, Senna nomame HQ833046와 같은 분계 조를 형성하며 $100 \%$ 의 확률로 유전적 신뢰도를 가지고 있음을 확인하였다(Figure 1B). 따라서 실험에 이용한 새싹인삼과 차풀 은 기존에 보고되어 있던 고려인삼 및 차풀과 유전적으로 일치 함을 확인하였다.

\section{2. 최적 배합비율에 따른 항산화 및 미백효과}

새싹인삼과 차풀 복합추출물의 최적 배합비율에 따른 항산화 및 미백효능 평가는 DPPH 라디칼 소거능과 tyrosinase 저해활 성 평가를 통하여 확인하였다. 최적 배합비율에 따른 항산화 효 능 실험 결과, 차풀의 비율이 증가할수록 라디칼 소거능이 증가 하였는데 그 중, 새싹인삼과 차풀의 배합비율(중량비)이 $1: 3$, $1: 5,1: 9$ 인 복합추출물을 비교하였다. 그 결과 새싹인삼과 차 풀의 비율이 $1: 5$ 보다 $1: 9$ 에서 라디칼 소거능이 유의적으로 증 가하였으며 $500 \mu \mathrm{g} / \mathrm{mL}$ 의 농도에서 새싹인삼과 차풀의 비율이 $1: 1,1: 5,1: 9$ 일 때 라디칼 소거활성이 각각 $64.7 \%, 74.9 \%$, $87.8 \%$ 의 저해율을 나타내는 것을 확인하였다(Figure $2 \mathrm{~A}$; Yoo et al., 2004). 따라서 새싹인삼과 차풀 복합추출물은 차풀의 함 

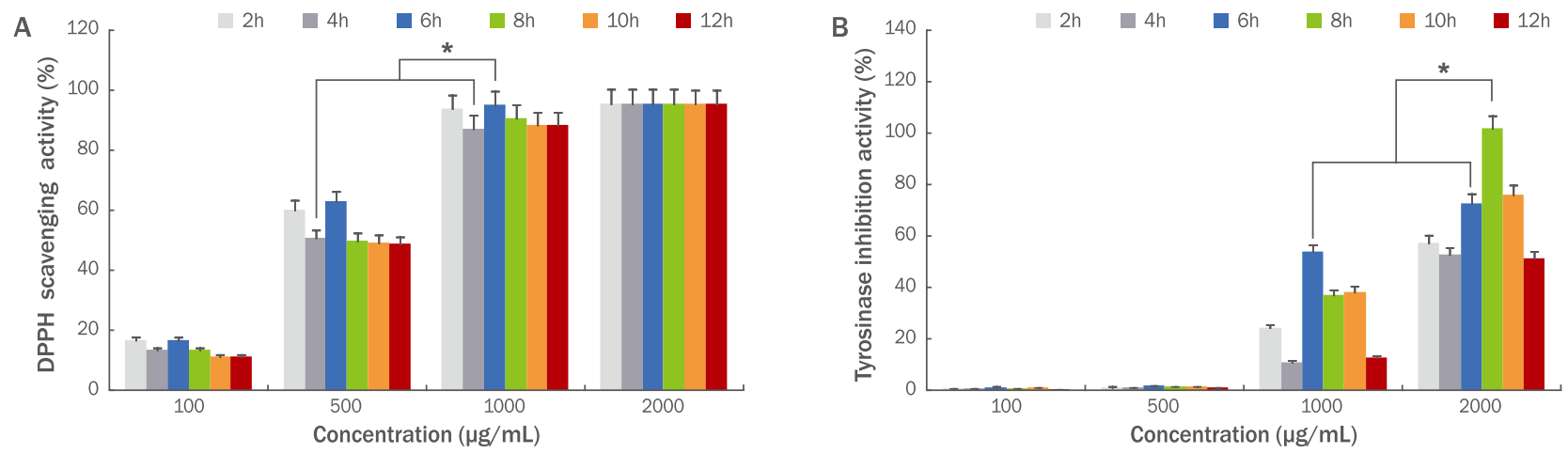

Figure 5. DPPH radical scavenging (A) and tyrosinase inhibitory activity (B) of complex extracts using sprout Panax ginseng C.A. Meyer and Cassia nomame (Sieb.) Honda as a function of time.

Extracts were freeze-dried and dissolved in 50\% DMSO. Each extraction time at various concentrations (100, 500, 1,000, 2,000 $\mu \mathrm{g} / \mathrm{mL}$ ) was interacted with DPPH and tyrosinase inhibitory activity. DPPH radical scavenging activity and tyrosinase inhibitory activity by extraction time was displayed in a dose-dependent manner. Each bar indicates the mean \pm standard deviation of determinations $(n=3)$. Statistical analysis was performed with a one-way ANOVA $\left({ }^{*} p<0.05\right)$. DPPH, 1.1-diphenyl-2-picrylhydrazyl; DMSO, dimethyl sulfoxide.

량이 증가함에 따라, 복합추출물의 농도가 증가함에 따라 항산 화 효과가 함량 및 농도의존적으로 활성이 증가함을 확인하였 다.

배합비율에 따른 미백활성 실험결과, 항산화 활성의 측정 결 과와 유사하게 새싹인삼과 차풀 비율에 따른 추출물의 미백활성 은 배합비율 $1: 1$ 보다 $1: 5$ 에서 유의적으로 효능이 향상되는 것 을 확인하였으며, $500 \mu \mathrm{g} / \mathrm{mL}$ 의 농도에서 비교한 결과, 새싹인 삼과 차풀의 비율이 $1: 1,1: 5,1: 9$ 일 때 미백활성은 $6 \%, 13 \%$, $22 \%$ 의 활성을 나타내었다(Figure 2B; Han \& Jung, 2003). 차풀 함량이 증가할수록, 복합추출물의 항산화 및 미백효능이 농도 의존적으로 향상됨을 확인하였다.

\section{3. 최적 용매비율에 따른 항산화 및 미백효과}

추출 용매 및 비율에 따른 항산화, 미백효과는 $0 \%, 10 \%$, $20 \%$ 및 $30 \%$ 에탄올로 추출 후 라디칼 소거능을 확인하였다. 항 산화 효능 시험 결과, $10 \%$ 에탄올 추출물과 $30 \%$ 에탄올 추출 물의 항산화 효능을 비교하였을 때 복합추출물의 항산화 효과가

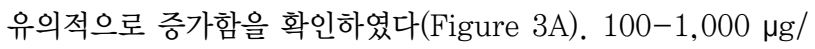
$\mathrm{mL}$ 농도에서는 $0 \%$ 에탄올에 비해 $10 \%$ 에탄올 추출 시 항산 화 효능이 증가하였고, 그 중 $100 \mu \mathrm{g} / \mathrm{mL}$ 에서는 에탄올의 함량 이 증가할수록(10-30\%) 항산화 효능이 증가함을 확인하였다.

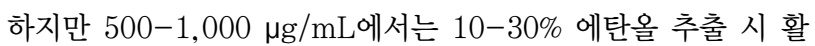
성의 차이를 크게 나타내지 않았다. 실험 결과 저농도 $(100 \mu \mathrm{g} /$ $\mathrm{mL}$ )에서 복합추출물 추출 시 에탄올의 함량이 증가할수록 항산 화 활성이 증가함을 확인하였다.

추출용매 및 비율에 따른 미백효과는 100-500 $\mu \mathrm{g} / \mathrm{mL}$ 농도 에서 $20 \%$ 에탄올보다 $30 \%$ 에탄올 추출 시 복합추출물의 미백
효과가 유의적으로 증가함을 확인하였다(Figure 3B). 따라서 새 싹인삼과 차풀의 배합비율이 $1: 9$ 인 경우, 최적의 항산화 및 미 백효과를 가지는 추출용매는 $30 \%$ 에탄올인 것으로 확인하였다.

\section{4. 최적 추출온도에 따른 항산화 및 미백효과}

새싹인삼과 차풀 추출 시 추출온도에 따른 효능을 확인하기 위하여 $20^{\circ} \mathrm{C}, 40^{\circ} \mathrm{C}, 60^{\circ} \mathrm{C}, 80^{\circ} \mathrm{C}, 100^{\circ} \mathrm{C}$ 추출 후 항산화와 미 백 효과를 측정하였다. 항산화 효능 평가 결과, $500-1,000 \mu \mathrm{g} /$ $\mathrm{mL}$ 에서 $60^{\circ} \mathrm{C}$ 와 비교하였을 때 $80^{\circ} \mathrm{C}$ 로 추출 시 복합추출물의 라디칼 소거능이 유의적으로 증가하였으며 항산화 활성이 매우 좋음을 확인하였다. 그러나 추출온도가 $80^{\circ} \mathrm{C}$ 에서 $100{ }^{\circ} \mathrm{C}$ 로 증가 시 모든 농도에서 라디칼 소거능이 오히려 감소함을 확인하였다 (Figure 4A).

추출 온도에 따른 미백효능은 $1,000-2,000 \mu \mathrm{g} / \mathrm{mL}$ 에서 $40{ }^{\circ} \mathrm{C}$ 와 $80^{\circ} \mathrm{C}$ 추출물의 효능을 비교하였을 때 $80^{\circ} \mathrm{C}$ 로 추출 시 유의적으로 활성이 증가함을 확인하였다. $500 \mu \mathrm{g} / \mathrm{mL}$ 에서는 $60{ }^{\circ} \mathrm{C}, 1,000-2,000 \mu \mathrm{g} / \mathrm{mL}$ 에서는 $80^{\circ} \mathrm{C}$ 에서 추출 시 높은 미 백 효능을 나타내었지만, 추출온도가 $80-100^{\circ} \mathrm{C}$ 로 높아지면 복 합추출물의 미백효과는 항산화 효능과 동일하게 오히려 감소하 는 것을 확인하였다(Figure 4B; Han \& Jung, 2003).

항산화 효능 및 미백활성 효능 실험 결과, 미백 효능은 500 $\mu \mathrm{g} / \mathrm{mL}$ 에서 $60^{\circ} \mathrm{C}$ 추출 시 가장 높았으나 고농도 $(1,000-2,000$ $\mu \mathrm{g} / \mathrm{mL}$ )에서는 $80^{\circ} \mathrm{C}$ 에서 좋은 활성을 나타내었으며, 항산화 효 능 또한 $500-1,000 \mu \mathrm{g} / \mathrm{mL}$ 에서 $80^{\circ} \mathrm{C}$ 추출 시 높은 활성을 나 타내었다. 따라서, 새싹인삼과 차풀의 배합비율 $1: 9$, 추출용매 $30 \%$ 에탄올인 경우, 최적의 항산화 및 미백효과를 가지는 추출 온도는 $80^{\circ} \mathrm{C}$ 로 결정하였다. 

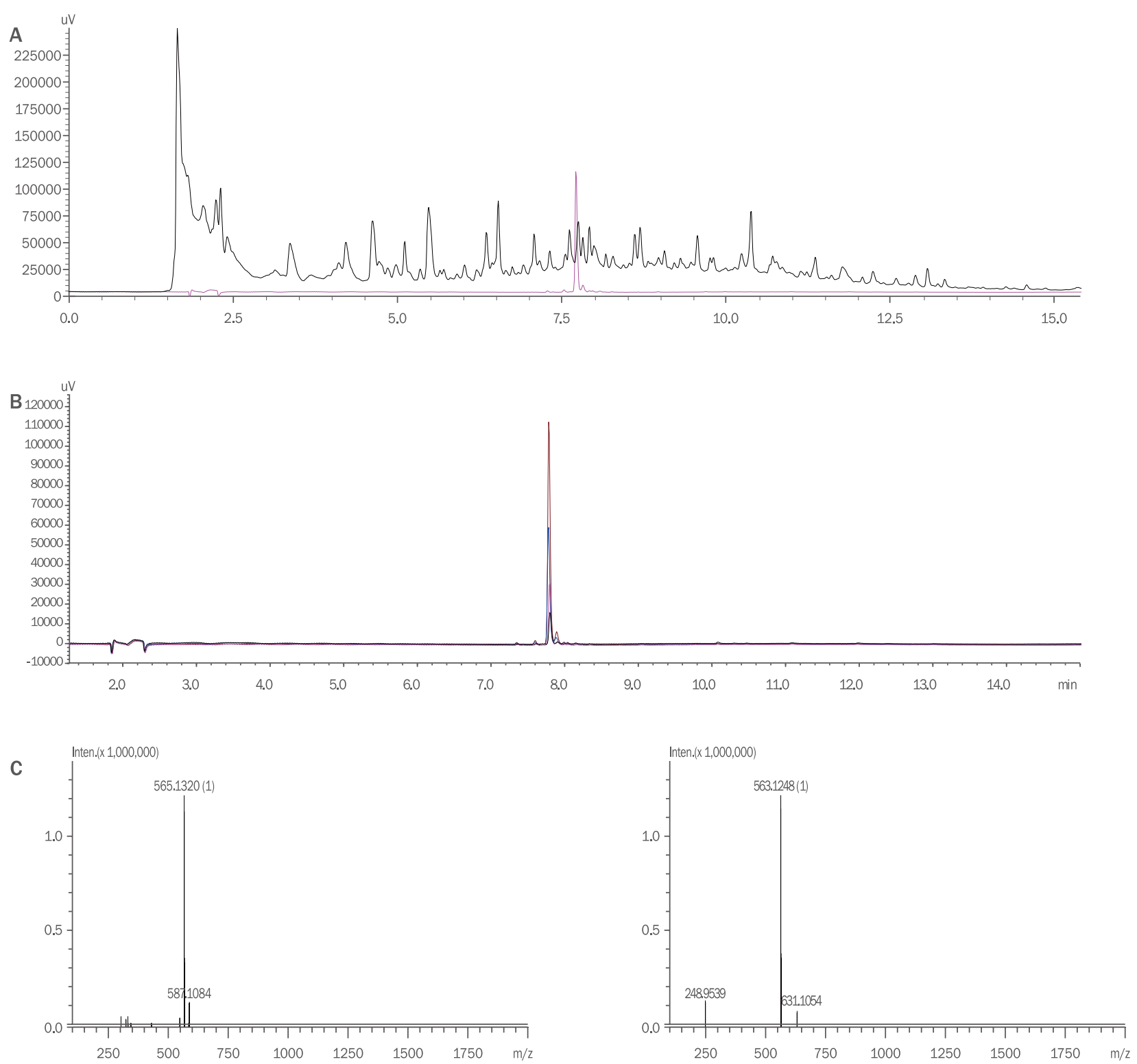

Figure 6. Screening of standard compound (A) HPLC analysis for Schaftoside (B) and molecular weight analysis using MALDI-TOF/MS of Schaftoside (C) of final complex extract using sprout Panax ginseng C.A. Meyer and Cassia nomame (Sieb.) Honda.

Acetonitrile and water were used as mobile phases. A Triart C18 PLUS column $(5 \mu \mathrm{m}, 250 \times 4.6 \mathrm{~mm})$ was used to separate the molecules. HPLC-separated fractions were analyzed by mass spectrometry to determine molecular weights. HPLC, high performance liquid chromatography; MALDI-TOF/MS, matrix-assisted laser desorption ionization time of flight mass spectrometer.

\section{5. 최적 추출시간에 따른 항산화 및 미백효과}

복합추출물의 최적 추출 시간을 확인하기 위하여 2-12 h 동 안 $2 \mathrm{~h}$ 간격으로 추출물을 회수하여 항산화 및 미백 효능을 평 가한 결과, Figure $5 \mathrm{~A}$ 에서 보는 바와 같이 복합추출물의 라디칼 소거능은 $100-1,000 \mu \mathrm{g} / \mathrm{mL}$ 농도에서 $6 \mathrm{~h}$ 추출 시 높은 소거 능을 나타내었으며, $500-1,000 \mu \mathrm{g} / \mathrm{mL}$ 에서 $4 \mathrm{~h}-6 \mathrm{~h}$ 을 비교한 결과 농도의존적으로 항산화 효능이 증가함을 확인하였다. 하지 만 $2,000 \mu \mathrm{g} / \mathrm{mL}$ 에서는 추출시간에 상관없이 효능의 차이를 보
이지 않았다.

미백효과의 경우 $100-500 \mu \mathrm{g} / \mathrm{mL}$ 에서는 추출 시간에 따른 활성이 큰 차이를 나타내지 않았으나 $1,000 \mu \mathrm{g} / \mathrm{mL}$ 농도에서 는 $6 \mathrm{~h}, 2,000 \mu \mathrm{g} / \mathrm{mL}$ 농도에서는 $8 \mathrm{~h}$ 추출한 복합추출물이 가 장 우수한 미백효과를 나타냈다(Figure 5B). 그러나 복합추출물 $2,000 \mu \mathrm{g} / \mathrm{mL}$ 농도에서 $6 \mathrm{~h}$ 추출물과 $8 \mathrm{~h}$ 추출한 복합추출물의 미백효과를 비교하였을 때 유의적으로 미백활성이 증가하였으며 $2,000 \mu \mathrm{g} / \mathrm{mL}$ 농도에서 각각 $77.9 \%, 109 \%$ 의 효능을 나타내었 
고, $8 \mathrm{~h}$ 추출 시 더 향상된 미백효과를 보이는 것으로 판단된다. 따라서 새싹인삼과 차풀의 배합비율 $1: 9,30 \%$ 에탄올, $80^{\circ} \mathrm{C}$ 로 추출 할 경우 최적의 항산화 및 미백효과를 가지는 추출시간은 8 $\mathrm{h}$ 으로 확인하였다.

\section{6. 지표성분 확인}

새싹인삼과 차풀 복합추출물에서 지표성분을 설정하기 위하 여 HPLC를 이용하여 복합추출물과 Chemface (China)에서 구 입한 샤프토사이드의 피크를 비교 분석하였다. 그 결과, 추출 물에서 샤프토사이드와 동일한 시간대에 피크를 확인하였으며 (Figure 6A), 복합추출물에서 분리한 물질이 샤프토사이드와 동 일 물질임을 확인하기 위하여 injection volume $10 \mu \mathrm{L}$, flow rate $1 \mu \mathrm{L} / \mathrm{min}, 37^{\circ} \mathrm{C}$ 조건에서 Triart C18 PLUS column을 이용하여 분석하였을 때 추출물에서 설정한 물질이 샤프토사이 드와 일치함을 확인하였다(Figure $6 \mathrm{~B}$ ). 추출물에서 단일 피크의 분자량 분석 결과, 샤프토사이드와 동일한 $563 \mathrm{~g} / \mathrm{mol}$ 임을 확인 하였고(Figure $6 \mathrm{C}$ ), 기존 라이브러리와 비교하였을 때 샤프토사 이드(Schaftoside)와 동일한 물질임을 확인하였다. 샤프토사이 드는 최근 천연화장품 조성물의 유효성분으로서 주목 받고 있으 며 저농도에서 월등히 우수한 콜라겐 합성 촉진 효과, 항산화 효 과, 항염증 효과 및 미백 효과를 나타내므로 피부 재생, 주름 개 선, 항산화, 항염증 및 피부 미백을 위한 의약품, 화장료, 건강식 품 등의 유효성분으로 사용 가능한 성분으로 알려져 있다(Woo \& Woo, 1989). 따라서 샤프토사이드가 포함된 새싹인삼 차풀 복 합추출물은 항산화 및 미백에 중요한 역할을 하는 것으로 판단된 다.

\section{Conclusion}

샤프토사이드 또는 이소샤프토사이드는 시계초(passionflower) 또는 석송강(Lycopodiella cernua)에서 추출된 물질에서 확인되는 유효성분이며, 미국 동부가 원산지로 미국 최 남부 및 하와이 등 열대지방에서 자생한다. 석송강은 한국의 전라남도 완도에서도 자생하는 것이 확인되었으나 수십 년 만에 발견될 만큼 귀한 식물 이다. 기존에는 샤프토사이드를 추출하여 사용하기 위해서는 석 송강만을 사용하여야 했기 때문에 나고야의정서에 따라 국제적인 분쟁이 발생할 우려가 있거나 식물을 구하기가 어려워 생산비용이 상승하는 문제점이 있었다.

본 연구에서는 이러한 문제점을 보완하기 위하여 국내 자생 새 싹인삼과 차풀 복합추출물을 이용하여 실험을 진행하였다. 새싹 인삼과 차풀의 혼합물에 대하여 열수추출 시 샤프토사이드를 지 표물질로 하는 복합물질을 추출 할 수 있으며, 복합추출물이 뛰 어난 항산화 및 미백효과가 있다는 것을 실험결과를 통해 확인하
였다. 또한 배합 비율, 추출용매, 온도, 시간에 따른 추출법을 확 립하였다. 새싹인삼과 차풀 배합비율은 $1: 9,30 \%$ 에탄올, $80^{\circ} \mathrm{C}$, $8 \mathrm{~h}$ 추출 하였을 때 뛰어난 항산화 및 미백효능을 검증하였지만, 지표물질로 설정한 샤프토사이드가 새싹인삼 혹은 차풀 중 어디 에서 유래한 것인지에 대하여는 추가적인 실험이 필요할 것으로 사료된다. 특히 유용한 천연화장품 원료로 주목 받고 있는 샤프 토사이드를 포함하는 복합추출물을 새싹인삼 및 차풀로부터 추 출하고 이를 산업적으로 이용한다면 국제적인 분쟁이나 고비용 으로 인한 산업적 이용의 제한으로부터 자유로울 수 있을 것으로 기대된다.

\section{Acknowledgements}

본 연구는 중소기업청에서 지원하는 2016년도 산학연협력기 술개발사업(과제번호C0453822)의 연구수행으로 인한 결과물임 을 밝힙니다.

\section{References}

Chen S, Yao H, Han J, Liu C, Song J, Shi L, Zhu Y, Ma X, Gao $T$, Pang $X$, et al. Validation of the ITS2 region as a novel DNA barcode for identifying medicinal plant species. PLOS ONE, 5: e8613, 2010.

Choe Y, Choe TB. Melanogenesis inhibitory effects of Allium hookeri extract in B16F10 mouse melanoma cell. Asian Journal of Beauty and Cosmetology, 12: 163-168, 2014.

Edgar RC. MUSCLE: multiple sequence alignment with high accuracy and high throughput. Nucleic Acids Research, 32: 1792-1797, 2004.

Han JS, Yi DH. Effects of pine needles fermentation extracts on antioxidant activity and inhibition of melanin synthesis. Asian Journal of Beauty and Cosmetology, 10: 619-624, 2012.

Han YS, Jung ES. A study of correlation between antioxidant activity and whitening effect of plant extracts. Asian Journal of Beauty and Cosmetology, 1: 11-22, 2003.

Hur SJ, Park EY, Ann MJ, Jang AR, Yang KS, Whang WK. A study on the whitening effects and HPLC pattern analysis of Cirsium setidens Nakai. Asian Journal of Beauty and Cosmetology, 8: 1-9, 2010.

Jo JE, Kim KH, Kim MS, Choi JE, Byun MW, Yook HS. Antioxidant activity from different root parts of 6-yearold Panax gingeng C.A. Meyer (Yun-poong). Journal of 
the Korean Society of Food Science and Nutrition, 40: 493-499, 2011.

Jeon KM, Park KH, Pyo AJ. A research on cell proliferation effect and antioxidant activity of extracts based on different extraction methods of Salvia miltiorrhiza Bunge and Scutellaria baicalensis. Asian Journal of Beauty and Cosmetology, 13: 495-502, 2015.

Jeong GH, Kim TH. Free radical scavenging and $\alpha$-glucosidase inhibitory effects of a roots extract of Aruncus dioicus var. kamtschaticus. Korean Journal of Food Preservation, 23: 989-994, 2016.

Kwon HJ. Anti-melanogenesis activity of Pleurotus eringii extracts. Asian Journal of Beauty and Cosmetology, 13: 695-700, 2015.

Kim EH. A study of whitening cosmetics from natural products. Asian Journal of Beauty and Cosmetology, 4: 195-203, 2006.

Kim JW, Moon JS, Choe TB. Comparison of antioxidant activity of Kenaf extract and its flavonoids. Asian Journal of Beauty and Cosmetology, 12: 203-210, 2014.

Kumar S, Stecher G, Tamura K. MEGA7: molecular evolutionary genetics analysis version 7.0 for bigger datasets. Molecular Biology and Evolution, 33: 18701874, 2016.

Lee HJ, Suh HJ, Lee HS. A study on the utilization of enzyme treated ginseng leaf for cosmeceutical ingredient. Asian
Journal of Beauty and Cosmetology, 8: 59-69, 2010.

Rhim SY, Choi HJ, Ryu TS, Kwon TR, Choi JK, Sohn JK. Analysis of major traits for native ginseng (Panax ginseng C.A. Meyer) collected from Poonggi area in Korea using DNA marker. Korean Journal of Crop Science, 55: 253-258, 2010.

Rhim TJ, Jeong H, Kim YJ, Kim DY, Han YJ, Kwon H, Kwon KR. A study on the comparison of antioxidant effects among cultivated ginseng, and cultivated wild ginseng extracts. Journal of Pharmacopuncture, 12: 7-12, 2009.

Tamura K, Nei M. Estimation of the number of nucleotide substitutions in the control region of mitochondrial DNA in humans and chimpanzees. Molecular Biology and Evolution, 10: 512-526, 1993.

Woo EH, Woo WS. Flavonoid glycosides from Melandrium firmum. Archives of Pharmacal Research, 12: 223-225, 1989.

Yang DH, Maeng S, Strain AK, Floyd A, Nielsen K, Heitman J, Bahn YS. Pleiotropic roles of the Msi1-like protein MsI1 in Cryptococcus neoformans. Eukaryotic Cell, 11: 14821495, 2012.

Yoo YG, Joung MS, Lee YH, Choi JW, Kim JH, Paek KY. A study on the effect of mountain ginseng adventitious roots extract. Journal of the Society of Cosmetic Scientists of Korea, 30: 377-383, 2004. 


\section{국문초록}

\section{새싹인삼과 차풀 복합추출물의 피부 항산화 및 미백효과}

김건우 ${ }^{1}$ 최윤희 ${ }^{1}$, 김병록 $^{1}$, 김영욱 $^{1}$, 성락선 $^{1}$, 한민희 ${ }^{1}$, 김경애 $^{2}$, 최민주 ${ }^{2}$, 정용기 $^{1 *}$

${ }^{1}$ (재)전남생물산업진흥원 천연자원연구센터, 전라남도 장흥군, 한국

${ }^{2}$ (주)하연 R\&D 연구센터, 광주, 한국

목적: 본 연구에서는 천연소재인 새싹인삼과 차풀의 복합추출물을 이용하여 항산화 및 미백효과를 입증하고, 최적의 원료 표준화 과정을 통해 차별화된 천연 화장품 소재를 개발하고자 하였다. 방법: 유전분석을 통한 새싹인삼과 차풀 각각의 연구소재를 준비하 고, 최적의 항산화 및 미백효과를 갖는 새싹인삼과 차풀 복합추출물의 배합비율, 용매비율, 추출온도 및 추출 시간 등을 결정한 후, 최종 복합추출물로부터 지표성분을 설정하였다. 결과: 새싹인삼과 차풀의 배합비율 $1: 9,30 \%$ 에탄올, $80^{\circ} \mathrm{C}, 8 \mathrm{~h}$ 추출하였을 때 최 적의 항산화 및 미백효과를 나타내었다. 복합추출물의 DPPH 라디칼 소거능 실험 결과, $500 \mu \mathrm{g} / \mathrm{mL}$ 에서 $49.6 \%$ 의 소거능을 보였으 며, 타이로시네이즈 미백활성은 $2,000 \mu \mathrm{g} / \mathrm{mL}$ 에서 $109 \%$ 활성이 저해됨을 확인하였다. 지표성분은 샤프토사이드(Schaftoside)로 설 정하였다. 결론: 본 연구는 새싹인삼과 차풀의 복합추출물로부터 최적의 항산화 및 미백효과를 얻기 위한 추출법을 규명하였다. 또 한 향후 샤프토사이드를 포함하는 천연 화장품 원료로써 이를 산업적으로 이용한다면 생산공정에서의 고비용으로 인한 산업적 이 용의 제한으로부터 자유로울수 있을 것으로 기대된다.

핵심어: 새싹인삼, 차풀, 항산화, 미백, 샤프토사이드

본 연구는 중소기업청에서 지원하는 2016년도 산학연협력기술개발사업(과제번호C0453822)의 연구수행으로 인한 결과물임을 밝 힙니다.

\section{참고문헌}

권혜진. 새송이버섯(Pleurotus eringii) 추출물의 미백효능 평가. 아시안뷰티화장품학술지, 13: 695-700, 2015. 김은화. 천연 추출물을 이용한 미백화장품 개발 동향에 관한 연구. 아시안뷰티화장품학술지, 4: 195-203, 2006. 김정원, 문지선, 최태부. 양마 추출물과 플라보노이드의 항산화활성 비교. 아시안뷰티화장품학술지, 12: 203-210, 2014. 전경미, 박경희, 표애자. 단삼과 황금의 추출방법을 달리한 세포증식 효과 및 항산화 활성효과 연구. 아시안뷰티화장품학 술지, 13: 495-502, 2015.

정경한, 김태훈. 재배 삼나물 뿌리 추출물의 자유 라디칼소거 및 $\alpha$-glucosidase 저해활성. 한국식품저장유통학회지, 23: 989-994, 2016.

조지은, 김경희, 김미선, 최재율, 변명우, 육홍선. 6 년생 인삼(연풍)의 뿌리부위별 항산화 활성. 한국식품영양과학회지, 40: 493-499, 2011.

유영근, 정민석, 이윤희, 최종완, 김중회, 백기엽. 산삼부정근 추출물의 효능-효과에 관한 연구. 대한화장품학회지, 30 : 377-383, 2004.

이현정, 서형주, 이현순. 효소처리 인삼잎 추출물의 화장품 소재 가능성 연구. 아시안뷰티화장품학술지, 8: 59-69, 2010. 임순영, 최홍집, 류태석, 권태룡, 최진국, 손재근. DNA marker를 이용한 풍기 재래인삼의 주요 특성 분석. 한국작물학회

지, 55: 253-258, 2010.

최연선, 최태부. B16F10 mouse melanoma 세포에서 삼채(Allium hookeri) 추출물의 멜라닌 형성 억제 효과에 관한 연

구. 아시안뷰티화장품학술지, 12: 163-168, 2014.

한정선, 이동희. 솔잎 발효액의 항산화 활성 및 멜라닌 생성 억제 효과. 아시안뷰티화장품학술지, 10: 619-624, 2012. 
한영숙, 정은선. 천연식물추출물의 항산화력과 미백작용의 상관관계연구. 아시안뷰티화장품학술지, $1: 11-22,2003$.

허선정, 박은영, 안미자, 장아름, 양기숙, 황완균. 고려엉겅퀴의 HPLC 패턴 비교 및 미백활성 연구. 아시안뷰티화장품학 술지, 8: 1-9, 2010. 


\section{中文摘要}

\section{人参和豆茶决明复合提取物的皮肤抗氧化和美白功效}

金建佑 ${ }^{1}$, 崔允姬 $^{1}$, 金炳鹿 $^{1}$, 金榮旭 $^{1}$, 成樂宣 $^{1}$, 韓憵熙 $^{1}$, 金慶愛 $^{2}$, 崔玟柱 $^{2}$, 鄭容琦 $^{*}$

${ }^{1}$ (财) 全南生物产业振兴院天然资源研究中心, 全罗南道长兴郡, 韩国

${ }^{2}$ (株)何然R\&D研究中心, 光州, 韩国

目的: 在这项研究中, 利用人参和豆茶决明的天然提取物开发抗氧化和美白效果, 并通过最佳的原料标准化过 程开发差异化的天然化妆品原料。方法: 测定具有最佳抗氧化和美白效果的人参和豆茶决明复合提取物的混合 比例、溶剂比、萃取温度和萃取时间后, 从复合提取物中设定指标成分。结果: 当人参和豆茶决明比例 $1: 9$, 用 $30 \%$ 乙醇, $80^{\circ} \mathrm{C}, 8 \mathrm{~h}$ 提取时, 获得了最佳的抗氧化和美白效果。发现化合物提取物的浓度为 $500 \mu \mathrm{g} / \mathrm{mL}$ 时, 1.1-diphenyl-2-picrylhydrazyl (DPPH)自由基清除活性为 $49.6 \%$, 在浓度为 $2000 \mu \mathrm{g} / \mathrm{mL}$ 时, 酪氨酸酶活性抑 制了 $109 \%$ 的活性。指标成分设定为Schaftoside。结论: 本研究旨在确定从人参和豆茶决明提取物中, 获得最 佳抗氧化和美白效果的提取方法。将来, 含有Schaftoside的天然化妆品原料应用于产业, 将不会受到因高成 分而限制工业用途的阻碍。

关键词: 人参, 豆茶决明, 抗氧化, 美白, Schaftoside 